\title{
Hackerlık Kavramı, Modeller ve Medyada Hackerlığın Sunumu
}

Serhat ÇOBAN, Onsekiz Mart Üniversitesi, İletişim Fakültesi Gazetecilik Bölümü, Dr. Öğr. Üyesi, serhatcoban@comu.edu.tr, ORCID: 0000-0001-8430-0681

$\ddot{O Z Z}$

Bu çalışmada hackerlık kavramının tarihsel süreç içinde yaşadığı değişimlerden bahsedilerek kavramın alanyazında ele alınış biçimlerinin bir modellemesi yapılmaya çalışılmıştır. Alanyazında temel olarak iki modelin yer aldığı saptanmıştır. Bunlar suç odaklı korumacı model ile özgürleşimci model olarak betimlenebilir. Çalışmadan çıkartılan bu modellemeler ekseninde medyanın hackerlık kavramını nasıl ele aldığ sorusuna da yanıtlar aranmıştır. 2019 yılının ilk altı ayında en çok ziyaret edilen Internet haber sitelerinin üçünde çıkan hacker temalı haberler eleştirel söylem analizi yöntemi ile incelenmiş ve korumacı modelin haberlerde daha yaygin bir kullanıma sahip olduğu görülmüştür.

Anahtar : : Teknoloji, Yazılım, Haber, Hacker, Söylem Analizi

Kelimeler

\section{The Concept of Hacking, Models and Presentation of Hacking in Media}

ABSTRACT

Keywords :

\section{Gíriş}

İletişim teknolojilerinin gündelik yaşam içinde oldukça önemli bir konumda olduğunu söyleyebilmek mümkündür.* Özellikle de İnternet'in gelişimi, akıllı telefonların, dizüstü bilgisayarların, iPad'lerin vb. teknolojik aygıtların yaygınlığı teknoloji merkezli bir dünya algısının oluşumuna zemin hazırlamaktadır. Teknolojinin günümüz toplumlarındaki yaygınlığı ve aldığı biçim teknolojiyi her şeyin belirlediği yanılgısına da kişiyi

\footnotetext{
*ỉletişim teknolojilerinin günümüz toplumlarında yaygınlığının artması, sayısal uçurum kavramının tümden yitip gittiği gibi bir algının oluşmasına da zemin hazırlamamalıdır. Küresel ölçekte sayısallaşmış bilgiye erişimde hala kısıtlı bölgelerin bulunduğu gerçeğinin yanında, ülkelerin hatta şehirlerin kendi içinde de sayısallaşmış bilgiye ulaşamayan kesimler bulunmaktadır. Bireylerin sayısallaşmış bilgiye ulaşmasına rağmen artan bilgi bombardımanına maruz kalması ve neye inanacağını bilememesi de içinde bulunulan çağın bir diğer özelliği olarak karşımıza çıkabilmektedir. Devletlerin ve şirketlerin sayısal bilgi üzerinde hegemonya kurmak istemesi de yine sayısallaşmış bilgi konusunda bir başka sorunsalı oluşturur.
} 
sürükleyebilmektedir. Bununla birlikte böyle bir teknolojik determinist yaklaşıma düşmeden toplumun da teknolojiyi etkilediği noktalara değinmek anlamlı sonuçlara ulaşmaya yardımcı olacaktır.

Teknoloji toplumdan ya da tarihsel süreçlerden bağımsız bir biçimde var olmamakta, toplumdaki güç-iktidar ilişkileri ya da çatışmaları teknoloji politikalarını belirleyebilmektedir. Teknolojiye ilişkin gücü elinde bulunduranlar ile bu güce sahip olamayanlar arasında oluşan gerilimlerin incelenmesi bu anlamda önem taşımaktadır. Bu çalışmada hackerların teknoloji ile kurduğu ilişki ve bu ilişkinin toplumsal boyutunun irdelenmek istenmesinin temel gerekçesi de kavramın teknoloji dolayımı ile güç-iktidar odakları ile yaşadığı gerilimli noktaların ele alınıp değerlendirilmesi arzusudur. Bu anlamda çalışmada hackerlığı ele alış biçimine göre modeller ortaya konulmuş ve İnternet haber sitelerinde yayınlanan hacker temalı haberler eleştirel söylem çözümlemesi yöntemi ile incelenerek hangi modelin haberlerde yaygın bir biçimde kullanıldığı serimlenmeye çalışılmıştır.

Günümüz teknolojilerinin oluşumunda büyük bir paya sahip toplumsal bir grup olan hackerların güç ilişkileri bağlamında tarihsel süreç içinde geçirdiği kavramsal dönüşümlerin izleri de bu çalışmada ele alınmıştır.

\section{Teknoloji, Toplum ve Hackerlık}

İnsanlık tarihi incelendiğinde uygarlığın oluşumunun sınıflı topluma geçiş süreci ile başladığ1 görülmekle birlikte bu toplumda bilginin önemli bir faktör olarak öne çıtı̆̆ı göze çarpmaktadır.

Artı değerin toplumdaki güç ilişkileri bağlamında nasıl bir dağılım göstereceği olgusu bilgi kavramının önemini ortaya çıarır. Yerleşik yaşama geçme ve artı değer üretmeyle bitlikte bilginin kullanılıp işlenmesi daha sistematik bir biçim kazanmıştır. Başat sınıf, bilgiye hâkim olmasıyla bağlantılı olarak bağımlı gruplar üzerinde etkide bulunabilmiş, onların rızasını alarak toplumsal sistemi yeniden üretebilmiştir (Şenel, 2011).

İlk insanların gelişimlerinde hayati bir rol oynayan bilgi içinde bulunulan yüzyılda teknoloji kavramı ile sıç̧a anılır olmuş, güncel gelişmeler ışığında "Bilgi Toplumu" külliyatı oluşmuştur. Teknolojiye etimolojik özellikleri bağlamında bakıldığında "tekne" ve "logos" kelimelerinin birleşiminden geldiği görülür. Antik Yunancadan gelen bu iki kelimeden ilki olan "tekne" bir şeyi yapma, üretme anlamina gelirken, "logos" ise mantık kelimesinin kökenini oluşturmakla birlikte bilmek anlamına gelir. Bu anlamda teknoloji bir şeyi yapma, üretme bilgisi olarak ön plana çıkar. Bir şeyi üretmenin, elde etmenin bilgisi teknik olarak ele alınırken; bu bilginin toplumla kurduğu ilişki için ise teknoloji ifadesi kullanılır. Yani evde yapılan reçel belirli bir üretim bilgisini gerekli kıldığından tekniğin konusunu oluştururken, marketten alınan reçel fabrika üretimi sonucunda ortaya çıkmakta, yani toplumsallaşmış bir anlam kazanarak teknolojinin konusunu oluşturmaktadır. Fabrika üretimi sonucu sofraya 
gelen reçel artık toplumsalın alanına girerek emek-sermaye arasındaki mücadeleleri, yerli ve ithal mal gibi kavramları gündeme soktuğundan teknolojiyle bağlantılandırılarak değerlendirilir (Atabek, 2005, s. 63).

Toplumun gelişimi üretim ilişkilerinin yapısıyla diyalektik bir ilişki içinde olup bu ilişki içinde bilgi işleme teknolojilerinin önemli bir yeri bulunur (Timisi, 2003, s. 88-89). Castels de yeni iletişim teknolojilerinin yaygın bir biçimde kullanıldığı yakın toplumsal dönemi açıklarken enformasyonculuk kavramını kullanır ve bu dönemin temel teknolojik unsurunun yazılım geliştirme olduğunu ifade eder (Castells, 2005, s. 147-151).*

Enformasyonel toplumun yükselişi, bir bakıma yazılımın ortaya çıkışı ve enformasyonel toplumun baş bileşenlerinden biri haline gelişi ile bağlantılıdır. Bir tür enformasyon olan yazılım, bilgisayarların metalaşma süreci içinde 1960'lardan başlayarak donanımdan ayrı bir varlık kazanmaya başlar. Yazılım yalnızca enformasyon olmanın dışında, enformasyonun özellikli bir hali olan bilgi kapsamında değerlendirilmelidir. Böylece yazılım, haber ve eğlence gibi herhangi bir enformasyondan ayrılır. Bilişim teknolojilerinin enformasyonu sayısallaştırma sürecinde yazılımın hem bu sürecin baş aracı hem de sonucu olduğu unutulmamalıdır. Bu nedenle yazılım hem kendisi hem de diğer enformasyon ürünleri için bir üretim aracıdır (Gözükeleş, 2006).

Günümüzün bilişim devriminin yani yazılım geliştirmenin temellerini hackerların attığ1 söylenebilir. Onların tutku dolu çalışmaları ile yazılım dünyası gelişebilmiş ve güncel olarak kullanılan birçok teknolojik aygıt ortaya çıkabilmiştir (Sabancı, 2013, s. 21). Hackerlık kavramının yazılım geliştirimi ile toplumsal yaşam içinde daha fazla bilinirlik kazandığ söylenebilir (Halbert, 1997, s. 362).

\section{Hackerlik Kavramının Tarihsel Gelişimi}

Hacker terimi, 1960'ların başlarında Massachusetts Teknoloji Enstitüsü'nden (MIT) bir grup tutkulu programcının kendilerine hacker demeye başlamasıyla ortaya çıkmıştır (Halbert, 1997, s. 362). Walleij (2003, s. 2), hacker kültürünün büyük bilgisayar ağlarının yaratıldığ1 MIT de doğmasının bir rastlantı olmadığını belirtir. Bu dönemde MIT, öğrencilerinden bazılarının bilgisayar çalışmalarına kendisini çok fazla adadığını fark ederek onlara bağımsız çalışma izni tanımıştır. 1970'lerde elektronik cihazlara ilgi duyan MIT öğrencileri Tech Model Railroad Kulübü bünyesine toplanarak elektro-mekanik kumanda sistemi ile model demiryolu ağ üzerinde çalışmış ve bu çalışma oldukça beğeni toplamıştır. Böylece işin ne kadar başarılı ve

\footnotetext{
*Castells, teknoloji ve toplum ilişkisinde devletin önemli bir konumda olduğunu belirtir. Devletin teknolojik yenilikleri başlatması, yasaklaması ya da öncülüğünü üstlenmesi bağlamında teknoloji ve toplum arasındaki ilişkiyi anlamada önemli bir etken olduğunu kaydeder. Bunun için de Çin, Sovyet ve Japon toplumu örneklerini verir. Çin toplumunun Avrupa'nın coğrafi keşiflere başladığı döneme kadar güçlü bir teknolojik yapıya sahip olduğunu belirten Castells, bu durumun 1800'lü yıllara gelindiğinde değiştiğini, bunun temel nedeninin ise devletin teknoloji politikalarından uzaklaşması olduğunu belirtir (Castells, 2010, s. 5-13).
} 
beğenildiğini ifade eden "hack" kavramının kullanılmaya başlandığı görülür (Akdeniz, 2013, s. 10).

İlk hackerların çoğunun üniversite öğrencisi olması hackerların öğrenme, öğretme ve çalışma fikirlerinde "Açık Akademik Model” in etkili olmasını sağlamıştır. Bu modelin temel özelliği araştırma sürecinin katkıda bulunmak isteyen herkese açık olmasıdır. MIT'de bu model içerisinde hareket eden öğrenciler istediği yazılım kodlarını serbestçe kullanabilmiş, kodları istediği gibi değiştirebilmiş ve var olan kodları geliştirerek yeni kodlar yazıp başkalarının kullanımına sunabilmiştir. Bu öğrenciler bilgisayarda istedikleri kodu deneyerek birbirlerine tavsiyeler verebilmiş, yaptıkları üzerine tartışıp birbirlerinin hatalarını düzeltebilmişlerdir. Böyle bir yapı içinde ortaya çıkan ilk hackerlar doğal olarak bilginin kısıtlanmasına, gizlenmesine ya da sadece belli bir kesimin kullanımına açık olmasına karşı olmuşlardır. Onlar için temel yaklaşım bilginin daima özgür ve herkese açık olmasıydı. Günümüzde hackerların genel işleyiş modelinin açık akademi modeline dayandığı, birbirleri ile kod paylaşarak, birbirlerinden bir şeyler öğrenerek kendilerini geliştirdiği söylenebilir. Kod yazarken aralarında bir emir-komuta zincirinden ziyade yeteneklerinden dolayı bir başkasına duyulan saygının esas alındığı da belirtilmelidir. Bilgisayar dünyasında bu çalışma şeklinin dışında iş modelleri de zamanla ortaya çıkmıştır. Bazı yazılımcılar programlarının kodlarını kapatarak bu kodlara ulaşmayı, bu kodlar üzerinde değişiklik yapmayı cezalandırma yoluna gitti ya da kodlara ulaşmayı bazı şartlara bağladı. Bu durum hackerların tepkisini çekerek özgür yazılım, açı kaynak kodlu yazılım, Creaitive Commons lisansı gibi farklı sistemlerin oluşmasına neden oldu (Sabanc1, 2013, s. 18-19).

1980'lerin ortalarına gelindiğinde ise hacker kavramında bir değişimin ortaya çıktığı görüldü. Hacker kelimesi artık sadece olumlu bir kavramı değil, suç ile ilişkili olarak bilgisayar korsanlarını ifade etmek için de kullanılıyordu. Hackerlar ise oluşan bu kavram karmaşasını önlemek amacıyla sistem güvenliklerini kıran kişilere "cracker" demeye başladılar (Himanen, 2005, s. 10; Anar, 2006; Uçkan, 2013a, s. 46). Hacklemek fiili ise ilk kulanıldığında kabaca kesmek, bir işi idare etmek gibi görece olumlu anlamından sıyrılarak zamanla bir bilgisayardaki verilere izinsiz erişim sağlamak anlamına dönüştü (Taylor, 1999, s. 14).

1950'li yıllardan itibaren ortaya çıkan ilk kuşak hackerların etik yaklaşımları bilgisayarlara (bilgi sistemlerine) giriş hakkının herkese açık olması; tüm bilginin özgür olarak birilerine ait olmayarak kuşaklar boyu aktarılıp herkesin olması; sistemin gayri merkezîleşmesi için çaba göstererek otoriteyle mesafeli olunmasıdır (Levy, 1984; Uçkan, 2013b, s. 60).

Açık kaynak hareketi, linux temelli işletim sistemleri ve yazılımları, firefox tarayıcı, copyleft ve creative commons gibi telif haklarına/fikri mülkiyete uzanan konular hackerlık kavramının merkezinde yer alır. Hackerlık öğrenme ve bu öğrendiklerini paylaşma faaliyeti içinde bir tür yaratım olup hackerlara mitolojik kimliğini verenin de bu olduğu belirtilir. Hackerların kamusal alana müdahalesi kodlamayla, yazılım geliştirme ile mümkün olabilmektedir (Saka, 
2013, s. 36). Uçkan'da günümüzde üretilen birçok teknolojik aygıtın (bilgisayar, cep telefonu vb.) hackerların özgür çalışma ritimleri ile üretildiğini belirtir (2013a, s. 46).

Kimilerine göre siber uzayın kahramanları kimilerine göre ise siber uzayın kötü çocukları olarak görülen hackerlara yönelik yapılacak analizler iyi ve kötü karşıtlığının ötesinde nasıl bir etik formasyonla iş gördükleri bağlamında ele alınmalıdır (Gunkel, 2005, s. 596). Walleij de hackerları, iyi ve kötü olarak adlandırmanın ötesinde bilgi dünyalarını keşfetmeye çalışan insanlık habercileri olarak tanımlar (2003, s. 6).

\section{Alanyazındaki İki Farklı Model}

Hacker terimi kişi ve grupların yaklaşımlarına göre farklı bağlamlarda değerlendirilebilmektedir (Eriş, 2011, s. 25). Bu anlamda hackerlık olgusunu ele alan alanyazın incelenmiş ve iki temel paradigma içinden yola çıkan iki farklı modelin alanda yer aldığı saptanmıştır. Bunlardan ilki hackerlık olgusunu suç ile bağdaştırarak ele alan yaklaşımdır. Çalışmada bu yaklaşım suç odaklı/korumacı model içerisinde ele alınıp değerlendirilecektir. Diğeri ise hacker etiği nosyonu üzerinden hackerlığı suç olgusundan ayıran bir unsur olarak göze çarpmakta ve çalışmada özgürleşimci model olarak ele alınmaktadır. Tabii ki bu modeller arasındaki sınırların katı olmadığını geçişken olduğunu da belirtmek gerekir.

\subsection{Suç Odaklı/Korumacı Model}

Bu modelde hackerlık olgusu adli bir kategori çerçevesinde suç temelli değerlendirilmektedir. Türk Dil Kurumu sözlüğünde "hacker" terimine bakıldığında "bilgisayar korsanı" ibaresi göze çarpmaktadır (TDK, 2019). Türkiye Bilimler Akademisi'nin Bilim Terimleri Sözlüğü'nde ise "hacker" terimi yeteneğini çoğu zaman gizli bilgi kaynaklarına ulaşmak, bilgisayar ve ağlar üzerinde yasal olmayan işler görmek yolunda kullanan kötü niyetli usta bilgisayarcı" şeklinde tanımlanmıştır (TÜBA, 2019). Bu anlamda hackerlığa olan bakış açısının negatif bir yan taşıdığını belirtmek mümkündür.

İnternet teknolojisinin zamanla ticaret ve bilgi sistemleri ile entegre hale gelmesinin bu sistemlere yetkisiz erişim, bilgi hırsızlı̆̆ı gibi güvenlik odaklı yaklaşımların da ön plana çıkmasına zemin hazırladığı söylenebilir. Siber savaş olarak da adlandırılan bu durum yasa dışı örgütlerin/grupların İnternet'i kendi amaçları için kullanabileceklerini fark etmesi olarak kavramsallaştırılır. Yasa dışı örgütlerin/grupların psikolojik kampanya başlatmak, gönüllü kazanmak, finansman sağlamak, şiddeti teşvik etmek ve eğitim vermek gibi farklı amaçlar için İnternet'i kullandıkları ifade edilir. Bu örgüt ya da grupların bir diğer amacının ise ağ üzerinde koordineli saldırılar yapmak olduğu kaydedilir. Yasa dışı oluşumların İnternet'i hem örgütlenme amaçlı bir forum alanı olarak kullanmaları hem de bilgisayar ağı üzerindeki sitelere saldırı faaliyeti gerçekleştirmelerinden yola çıkılarak hackerlık faaliyetinin güvenlikçi bir bakış aşısından değerlendirildiği söylenebilir (Weimann, 2006, s. 2-6). Bu yaklaşımlar siber güvenlik olarak ön plana çıkmaktadır. Özgürlük ile güvenlik arasındaki denge oldukça hassas 
olmakla birlikte siber güvenliği tehdit eden birçok unsurun sayısal ortamda görüldüğü de belirtilir. Siber güvenliği tehdit eden saldırı araçları çeşitli olup bunlar bazen bir virüs, solucan, truva atı ya da casus yazılım olabilir. Kimi zaman ise kendisini bir bankanın resmi sitesi olarak gösteren sahte bir web sitesi olabilir. İnternet ortamında bilginin çarpıtılıp propaganda amaçlı kullanımı da yine siber alanda ortaya çıkan güvenlik boyutu ile ele alınabilir (Öğün ve Kaya, 2013, s. 151-152).

Terzi (2018, s. 92) siber terörizmi şu şekilde tanımlar:

"Siyasal içerikli olup siber ortamda, insanların da bir parçası olduğu siber sistemlere karşı bozma, sızma veya ihlal etmenin gerçekleşmesi veya gerçekleştirme tehdidi gibi bir hareketin neden olduğu engellenme sonucu, milyonların davranışını etkilemek ve günlük yaşamın gidişatını bozmak".

Hırsızlık, dolandırıcılık gibi suç fiillerinin fiziksel temasa gerek duyulmadan sayısal ortamda yapılabilmesi hackerlık kavramını siber güvenlik bağlamında değerlendiren çalışmaların ortaya çıkmasına da zemin hazırlamıştır. Bu çalışmalara göre hackerlık suç olgusu ile bağlantılıdır. Suç örgütleri ya da terör gruplarının sayısal ortamdaki etkinlikleri hackerlık kavramı ile ilişkilendirilerek değerlendirilmektedir. Hackerların sayısal ortamlardaki faaliyetleri hacking olarak adlandırılmakta ve bilgisayar sistemlerine yetkisiz erişimle bağlantılandırılmaktadır. Hackerların bilgisayar sistemlerine girdikten sonra belli bilgileri çaldığı, sisteme istediği zaman erişebilmek maksatlı arka kapılar oluşturduğu, sistemde bulunan bilgileri gizlice ağ üzerinden transfer edebildiği ifade edilir (Hekim ve Başıüyük, 2013, s. 140; Bronk ve Ringas, 2013, s. 8; Yor ve Steinmetz, 2019, s. 55).

Küresel örgütlerin yayınları ve açıklamalarına bakıldığında da hacker faaliyetlerinin güvenlik odaklı bir yaklaşımla ele alındığı söylenebilir. Dünya Ekonomik Formu 2019 Küresel Risk raporunda teknolojinin bireyler, hükümetler ve işletmeler için küresel risk ortamının şekillenmesinde derin bir rol oynadığı vurgulanarak siber suçların ekonomiye en büyük tehditlerden biri olduğunu belirtilmektedir. Raporda 2018 yılı içinde siber saldırıların kişisel bilgilerin ihlal edilmesine yol açtığı vurgulanır. Rapor incelendiğinde hackerlık faaliyetine ulusal güvenlik çerçevesinden bakıldığı görülmektedir. Hackerların devletin önemli sayısal ağlarına sızarak gizli bilgileri ele geçirebilme hususu da ulusal güvenlik bağlamında değerlendirilmektedir (WEF, 2019, s. 5-17). Kuzey Atlantik Antlaşması Örgütü (North Atlantic Treaty Organization - NATO) de yaptığı kurumsal açıklamalar ve raporlarında hackerlık olgusunu siber tehdit ve saldırılar bağlamında ele alır (NATO, 2018).

\section{2. Özgürleşimci Model}

Suç odaklı/korumacı modelin tersine özgürleşimci modelin hackerlık kavramına daha farklı anlamlar yüklediği söylenebilir. Hackerlık kavramı bu modelin içinde bilgi paylaşımı, bilginin sayısal ortamda serbest akışı ve ifade özgürlüğü nosyonları etrafında şekillenir. 
Hackerların İnternet üzerinde ortak derledikleri sözlükte (The New Hacker's Dictionary) "hacker" terimi genel anlamda asgari gereksinimlerle yetinen kullanıcılara zit olarak programlanabilir sistemlerle ilgili detayları keşfetmeyi ve onların kapasitelerini genişletmeyi seven, tutkuyla programlayan ya da herhangi bir şeyle ilgili tutku düzeyinde uzmanlaşan kişilere (örneğin astronomi hackeri olabilir) denir. Hacker terimi ilk olarak bir aletle marangozluk yapan kişiyi betimlemek için kullanılmıştır. "Hacker Etiği” terimi ise hackerları, bilgi paylaşımının olumlu bir etkiye sahip olacağına inanan insanlar olarak tanımlar. Hackerların özgür yazılım yazıp bilgiye ulaşımı kolaylaştırdığı ve bilgisayar işlem kaynaklarına mümkün olan her yerde ulaşım sağladığı belirtilen sözlükte hackerların etik görevlerinden birinin uzmanlıklarını paylaşmaları olduğu belirtilir (The New Hacker's Dictionary, 2018, s. 310).

Özgürleşimci model içinde hacker kavramına olumlu anlamlar yüklendiği görülmektedir. Hacker, bilgisayarlara ve benzeri araçlara ilgi duyan teknoloji insanı ya da sistemin sadece kullanıcıya sunduğu özelliklerle yetinmeyerek sistemi anlamaya çalışan bireyler olarak tanımlanır (Saka, 2013, s. 34; Uçkan, 2013b, s. 59).

Raymond (2006), hackerları yazılım kodlama üstatları ya da problem çözmekten zevk alarak sınırları aşan kişiler olarak tanımlar. Bilgisayar uygulamaları üzerinden yaratılan bir kültür sonucunda üstat-hacker teriminin ortaya çıktığını belirten Raymond, bu terimin sadece bilgisayar alanı açısından ele alınamayacağını, herhangi bir bilim ve sanat dalının en üst seviyesinde de görüldüğünü kaydeder. Üstat/hacker ile crackerlar arasında ayrım yapan Raymond, crackerların bilgisayar sistemlerini bozan ve telefon sistemlerini izinsiz kullanan insanlar olduklarını kaydeder. Temel fark burada üstatların bir şeyler kurması, inşa etmesi iken crackerların yani korsanların bunları bozmasıdır. Raymond üstatların felsefesine ilişkin verdiği bilgide bu kişilerin otoriter yaklaşımlara karşı olduklarını belirterek otoritenin sansürcülük ve gizlilik ile bağlantılı olduğunu, oysaki üstatların temel yaklaşımının gönüllü iş birliği ve bilgi paylaşımına dayandığını, üstatlıkta çalışmanın kendi başına bir zevk olarak algılandığını kaydeder. Hacker etiğinde şöhret ve statünün diğer insanlara egemen olmakla kazanılmadığını buna karşılık bir şeyler üreterek ve paylaşarak sağlandığını vurgular.

Özgürlük, mahremiyet, erişim gibi birtakım liberal prensipleri hackerların oldukça önemsediği görülür (Saka, 2013, s. 35). Himanen (2005: 11), hackerların üç etik kodla hareket ettiklerini belirtir. Bunlar; çalışma etiği, network etiği ve para etiğidir. Linux, kişisel bilgisayar, Net (İnternet ve World Wide Web), e-posta, ilk bilgisayar oyunu gibi bir yazılım sonucunda ortaya çıan yapıların özel şirketler ya da hükümetler tarafından değil de fikirlerini özgür bir ritimde çalıştıran benzer zihniyetteki hevesli kişilerle birlikte yaratıldığını belirten Himanen, bu durumu "hacker etiği" olarak betimler ve bu etiğin günümüz kapitalist toplum yapısının birçok değerine karşı ruhsal bir meydan okuma olarak da görülebileceğinin altını çizer. Bu anlamda hacker etiğinin bu ruhsal meydan okumasının bir yönünün Max Weber'in klasik 
yapıtı "Protestan Ahlakı ve Kapitalizmin Ruhu"nda ifade edilen çalışmaya karşı bir meydan okuyuş olarak da görülebileceğini kaydeder.

Hackerların çalışma felsefesinin temelini; istedikleri, sevdikleri şeyleri zamana bağlı olmadan yapabilme yaklaşımı oluşturur. Bu şekilde daha başarılı ve verimli olabildiklerini fark eden hackerların programlanmış bir yaşam ritmindense daha özgür bir yaşam ritmini savundukları kaydedilir. Çalışma bu yaklaşıma göre keyif alınan konuya, keyif alınan zamana çekilmiş ve protestan ahlakının istediği çalışma etiğine tezat bir konum edinmiştir. Protestan çalışma etiğinin zorunluluklar üzerine kurulu daha planlı bir biçimde işlediği görülürken; hackerların çalışma etiği ise iş odaklı bir yaklaşımdan tutku odaklı bir yaklaşıma doğru kayışı gösterir (Sabanc1, 2013, s. 19).

Himanen (2005, s. 11-12), toplumsal yapıya meydan okuyuşun bir diğer boyutunun hacker para etiği olduğunu belirterek ${ }^{*}$ kapitalist toplum yapısında para kazanmanın genellikle bilgiyi paylaşmaktan ziyade bilgiye sahip olarak onu saklama biçiminde ortaya çıktığını bu durumun ise hacker para etiğiyle tezat oluşturduğunu ifade eder. Himanen'e göre hacker para etiği genellikle bilgiyi paylaşmayı esas alır, bununla birlikte tüm hackerlar tarafından bu paylaşımcı modelin kabul edilerek uygulanabildiğini söyleyebilmek de güçtür. Hacker etiğinin bir diğer unsuru ise network etiği ya da netikdir. Netik, İnternet üzerindeki ifade özgürlüğü ya da herkesin İnternet'e erişebilme özgürlüğü gibi fikirlere gönderme yapar. ${ }^{+}$ Hackerların savunduğu bilginin özgür olması yaklaşımı gücün kimsenin elinde olmaması anlamına gelir. Hackerlar bilginin kısıtlanmasını meraklarını tatmin etme arzusunun önünde büyük bir engel olarak gördügünden bu yaklaşıma ciddi bir refleks gösterirler (Sabanc1, 2013, s. 23).

Linus Torwalds (2005, s. 17) hackerların "yaratma" davranışının altında yatan temel dürtülerin ne olduğunu ele alırken bunun toplumsallaşma ve heyecan olduğunu belirtir. Hacker kültürünün tanınmış savunucularından biri olan Eric Raymond (2008, s. 36) ise Hacker faaliyetinin ruhunu özetlemek için Torvalds'ın eğlence kelimesine denk düşen tutku kelimesini kullanır. Tutku özünde ilginç, ilham ve keyif verici bir faaliyete kendini adamayı ifade eder. Bu kendini adamanın arka planında ise bireyin kendi egosunu tatmin etme isteğinin yattığını belirtir. Raymond ayrıca yapılan işten zevk alındığını, bunun da başarıyı arttırdı̆̆ını söyler.

Hackerlık olgusunun toplum içinde tanıtılmasında, anlaşılmasında medyanın da büyük bir önemi olduğu söylenebilir. Medyada hackerlık kelimesi sıklıkla kullanılmakta ve çoğu

\footnotetext{
*Weber de para etiğini Protestan ahlakının diğer ana unsuru olarak da tanımlamıştır.
}

${ }^{+}$Hackerların sayısal bilginin metalaştırılmasına, hükümetlerce denetim altında bulundurulmasına, şirketlerce gözetim altında tutulmasına karşı sayısal teknolojileri geliştirmek amaçlı çabalar içine girdikleri de belirtilmelidir (Boschele ve Öztürk, 2017: s. 448). 
zamanda kelimenin basmakalıp ifadeler ile ele alındığı göze çarpmaktadır (Sabancı, 2013, s. 22). Bu çalışmada eleştirel söylem analizi yöntemi ile medyada hackerların nasıl ele alındığı incelenecektir.

\section{Yöntem}

Her olay haber sayılmayıp bir olayın haber olmasına ilişkin çeşitli profesyonel etik kodlar geliştirilmiştir. Bu etik kodlar ile de haberde nesnelliğin sağlandığ 1 ve herhangi bir yanlılı̆̆ın yaşanmadığı iddia edilmektedir. Bu yaklaşımın gelişmesinde yasama, yürütme ve yargıdan sonra medyanın dördüncü güç olma nosyonunun liberal paradigma ile öne çıkartılma itkisi de yatar (İnal, 1996). Basın kuruluşlarının dar bir politik gruba değil de herkese hitap ederek tecimsel gücünü arttırma isteği de haberde profesyonel etik kodların ve haber değerlerinin oluşumunda etkilidir (Taş, 2012). Bu durumla birlikte özellikle medya çalışmalarında 1970'li yıllardan sonra sıkça kullanılan söylem analizi yöntemi ile profesyonel etik kodların haberde kullanılmasının haberde nesnellik taşıyacağı iddiasına yönelik eleştirel bir tutum sergilenmektedir. Medyanın kullandığı dil ve fotoğraflarda olayların temsili bir bilgisinin sunulduğu ve bu temsillerin gerçekliğin belirli bir ideolojik kesitini yansıttı̆̆1 iddia edilir (Baker, Gabrielatos ve McEnery, 2013, s. 3).

Söylem analizinin farklı disiplinlerden gelen birçok araştırmacı tarafından kullanıldığını söyleyebilmek mümkündür. Çeşitli disiplinlerden gelen bu araştırmacılar söylemin farklı boyutlarına yoğunlaşmaktadır (Brown ve Yule, 1983). Söylem çözümleme yönteminin 1970'li yıllardan sonra yaygınlık kazandığı görülmekle birlikte eleştirel haber söylem çözümleme yöntemlerinin ise 1990'lı yıllardan sonra post yapısalcılık kavramı ile geliştiği söylenebilir (İnal, 1996, s. 26-27).

Eleştirel söylem çözümlemesi, söylem analiz tiplerinden biri olup temelde toplumsal ve politik bağlam içinde güç ve eşitsizlik olgularına odaklanır. Bazı araştırmacılara göre İkinci Dünya Savaşı'ndan önce Frankfurt Okulu tarafından bulunmuştur. Eleştirel dilbilim çalışmalarının da öncülüğünde geliştirilen bu yöntem 1960 ve 1970'li yıllardaki egemen resmi paradigmaya (toplumsal ve eleştirel olmayan) bir tepki olarak gelişimini sürdürmüştür (van Dijk, 2001, s. 352).

Fairclough ve Wodak (1997, s. 271-280) ise eleştirel söylem çözümlemesinin temel yönelimlerinin söylemin tarihsel ve ideolojik olduğu yaklaşımını kabulle toplumsal sorunlara odaklanma olduğunu belirterek eleştirel söylem çözümlemesinin temel yönelimlerinin şunlar olduğunu belirtir.

1. Toplumsal sorunlara odaklanir.

2. Güç ilişkileri belirsizdir.

3. Söylem, toplum ve kültür tarafından oluşturulur. 
4. Söylem ideolojiktir.

5. Söylem tarihseldir.

6. Söylem, metin ve toplum arasında aracılık yapar.

7. Söylem çözümlemesi, yorumlayıcı ve açıklayıcıdır.

8. Söylem, toplumsal etkileşimin bir formudur.

Fowler (1991, s. 46-65), gazete metinleri üzerine yaptığı söylem incelemesinde konsensüs olgusu üzerinden güç-iktidar ilişkisini açımlamaya çalışır. Gazetelerde yer alan rüşvet, tecavüz, yolsuzluk, bağnazlık gibi olaylara ilişkin yaptığı incelemede konsensüs sınırlarının dışında dolaşan insanlara hükümler verildiğini, bu insanların "huzur bozucu", "sapık", "normal dışı", "muhalif", "sıkıntı yaratan" olarak damgalandığını saptar. "Biz" ve "öteki" olguları üzerinden damgalamalara girişildiğini kaydeder. "Biz" konsensüsü daraltılmış ve pekiştirilmiştir. Nüfus anlamında "biz" kültürel ve ekonomik olarak aynı çıkarlara sahip olan insanları tanımlar. "Biz", düşmanlar yani "onlar" tarafından tehdit ediliriz. Birçok haber "onlar" kurgusuyla birçok olumsuz tutum ve davranışları karakterize eder. Böylece gazeteler cinayet, tecavüz, casusluk, isyan, doğal felaket yani ötekilere ait hikayelerle doldurulur.

van Dijk'e göre (van Dijk, 2001: s.353) söylem çözümlemesi yönteminde şunlara dikkat edilir:

1. Temelde toplumsal sorunlar ve politik konulara odaklanır.

2. Toplumsal sorunların eleştirel analizinde çok disiplinli yöntemlerden faydalanır.

3. Söylemin yapısına odaklanmaktan ziyade, toplumsal etkileşim ve toplumsal yapı bağlantısını kurmaya çalışır.

4. Güç ve egemenlik ilişkileri bağlamında söylemin nasıl ortaya çıtı̆̆ını, kabul edildiğini, meşruluk kazandığını, yeniden üretildiğini ve başat söylemlere nasıl meydan okunduğunu ele alır.

Söylem çözümleme alanında önemli çalışmaları olan van Dijk'a göre bir söylem çözümleme modeli aşağıdaki kategorilerden oluşur (Özer, 2009: 92-93). 
Tablo1. van Dijk'in Söylem Çözümleme Modeli

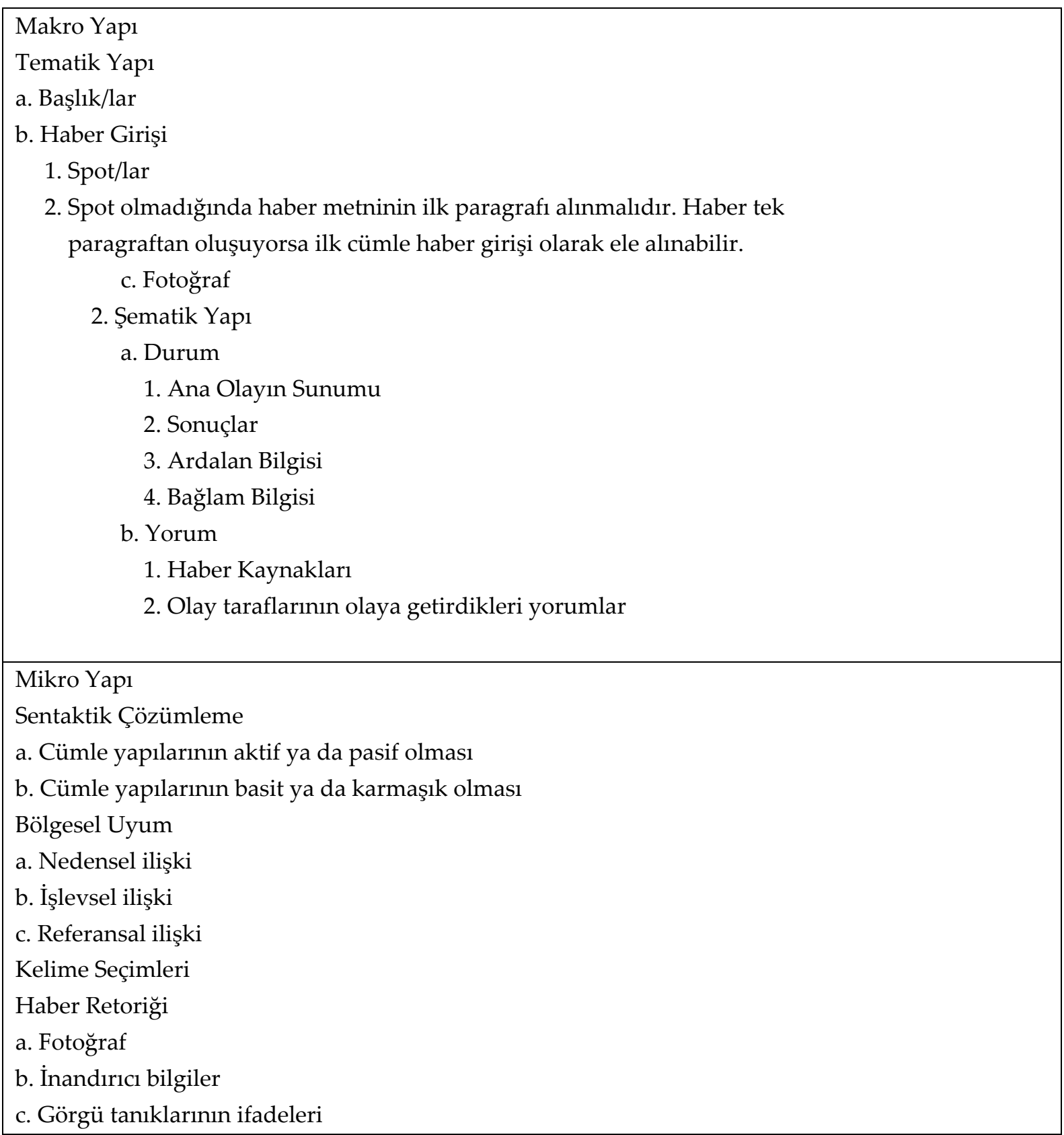

Bu çalışmada van Dijk ve Fowler'ın yaklaşımları temelinde İnternet'teki haber sitelerinde yer alan haber metinlerinde hackerlığın nasıl temsil edildiği incelenmeye çalışılacaktır. İncelenen İnternet haber siteleri Alexa şirketinin sunduğu veriler ışığında seçilmiştir. Alexa şirketi İnternet'teki web sayfalarının ziyaretçi trafikleri ile ilgili istatistiki bilgileri kamuoyu ile paylaşmaktadır. İlk olarak şirketin İnternet sitesi incelenmiş ve Türkiye'de en çok ziyaret edilen web siteleri saptanmıştır. Daha sonra en çok ziyaret edilen web siteleri arasında ilk üç sırada yer alan haber siteleri saptanmış ve 01.01.2019 ile 30.06.2019 tarihleri arasındaki altı aylık periyodda bu sitelerde yer alan "hacker" temalı haberler söylem çözümlemesi yöntemi ile incelenmiştir. Söylem çözümlemesi yönteminin makro ve mikro yapısından seçilen "Haber 
Başlıkları, Haber Girişleri, Kelime Seçimleri” kategorileri çalışmanın sınırlılığını oluşturmaktadır. Alexa sitesinden 23.08.2019 tarihinde alınan veriler ışığında Türkiye'de en çok ziyaret edilen ilk üç haber sitesi aşağıda verilmektedir.

1. ensonhaber.com (6. sirada)

2. hurriyet.com.tr (10. sirada)

3. aksam.com.tr (13. sirada) (Alexa, 2019).

\section{Bulgular ve Yorum}

Haber siteleri incelendiğinde konuyla ilgili Ensonhaber.com sitesinde dört haber, Hürriyet.com.tr haber sitesinde elli beş haber, Aksam.com.tr haber sitesinde ise dokuz haberin yer aldığı saptanmıştır.

\subsection{Ensonhaber.com}

\subsubsection{Haber Başlıkları}

Çalışmanın konusu bağlamında Ensonhaber.com adlı haber sitesinde konu ile ilgili altı aylık bir zaman dilimi içinde çıkan dört haber incelenmiş ve incelenen haber başlıklarının üçünde hackerların negatif bir biçimde ele alındığı, birinde ise daha tarafsız bir yaklaşımın sergilendiği görülmüştür.

Haber sitesinde hackerları negatif bir biçimde ele alan başlıklar şunlardır:

Hackerlar 40 milyon dolarlık bitcoin çaldı (09.05.2019)

Kuzey Koreli hacklerlar 100'den fazla şirkete saldırdı (04.03.2019)

Özge Ulusoy'un başı hacker'larla dertte (20.02.2019)

Haber sitesinde hackerları negatif bir biçimde ele alan başlıklarda kullanılan metafor kelimelerin şunlar olduğu belirtilebilir:

$$
\begin{aligned}
& \text { "çaldı" } \\
& \text { "saldırdı" } \\
& \text { "dertte" }
\end{aligned}
$$

Haber sitesinde hackerları tarafsız bir biçimde ele alan haber başlığı ise aşağıdadır:

NASA'yı hackleyen hacker: Canım sıkıldı (27.04.2019)

Haber sitesinde hackerları tarafsız bir biçimde ele alan başlıkta kullanılan metafor kelimenin ise "hackleme" olduğu belirtilebilir. Bu kelimenin kullanılışı ile nötr bir yaklaşım içerisinde 
olunduğu belirtilse de bu kelimenin gündelik yaşamda negatif çağrışımlar yaptığ vurgulanmalıdır. Kelime suça ilişkin göndergesel öğeler taşımaktadır.

\subsubsection{Haber Girişleri}

Çalışmanın konusu bağlamında Ensonhaber.com adlı haber sitesinde analiz edilen haber girişlerinin kullanılan başlıklarla paralellik taşıdığı belirtilmelidir.

Hackerları negatif bir biçimde ele alan başlıkların kullanıldığı haberlerin örnek haber girişleri aşağıdadır:

Küresel kripto para platformu Binance' in CEO'su Changpeng Zhao, hackerlarm toplam 40 milyon dolarlık bitcoin çaldıklarını açıkladı (09.05.2019).

New York Times gazetesi, Kuzey Koreli hackerların geçen haftadan itibaren saldırılar düzenlediğini aktardı (04.03.2019).

Hacker'ların saldırısına uğrayan ünlü manken Özge Ulusoy, hesabını kapattı (20.02.2019).

Hackerları tarafsız bir biçimde ele alan başlığın kullanıldığı haberin örnek haber girişi aşağıdadır:

Siber Güvenlik Uzmanı Chris Roberts, NASA'yı hackledi. Roberts, bunu can sıkıntısından dolayı yaptı̆̆ııı açıkladı (27.04.2019).

Hackerları tarafsız bir biçimde ele alan haber metninin ardalanı okunmaya çalışıldığında hacklemek kavramının suça ilişkin göndergelerinin bulunduğu da belirtilmelidir.

\subsubsection{Kelime Seçimleri}

Haber metinlerinin bütünü incelendiğinde kelime seçimlerinin haber metninin yapısına uygun olduğu görülmektedir.

Hackerları suç ile bağlantılı olarak ele alan haber metinlerinde kullanılan kelimeler şunlardır:

$$
\text { "çaldı", "ele geçirdi", "hırsızlık", "saldırı", "siber saldırı", "hedef alma" }
$$

\subsubsection{Değerlendirme}

Ensonhaber.com adlı İnternet haber sitesi değerlendirildiğinde hackerların genel olarak suç odaklı model doğrultusunda kavramsallaştırıldığı görülmektedir. Gerek haber başlıkları, gerekse de metin içinde kullanılan kelimeler ve ifadeler hackerları negatif bir biçimde damgalamaktadır. Fowler'ın da vurguladığı gibi iyi ve kötü kavramsallaştırması üzerinden hackerlar kötü olarak tanımlanmakta ve haber metninin bu şekilde kapanması sağlanmaktadır. 


\subsection{Hürriyet.com.tr}

\subsubsection{Haber Başlıkları}

Çalışmanın konusu bağlamında hurriyet.com.tr adlı haber sitesinde konu ile ilgili altı aylık zaman dilimi içinde çıkan elli beş haber incelenmiş ve incelenen haber başlıklarının kırk sekizinde hackerların negatif bir biçimde ele alındı ̆̆ı, birinde tarafsız bir yaklaşımın sergilendiği, altısında ise pozitif bir tutumun benimsendiği görülmüştür.

Haber sitesinde hackerları negatif bir biçimde ele alan başlıklardan bazıları şunlardır:

Siber saldırı sonucu 106 milyon kişinin verileri çalındı (30.07.2019)

İranlı hacker grubu Outlook üzerinden kurbanların vuruyor (08.07.2019)

Flipboard hack'lendi, kullanıcıların bilgileri çalındı! (30.5.2019)

Kara Şovalye'nin hacker'ı çıktı! 10 milyonluk çete çökertildi (09.05.2019)

Hacker'lar işi abarttı, 30 milyar kez sızmayı denedi! (03.05.2019)

'Siber saldırıların yarattığı hasar yaklaşık 3 trilyon dolar' (16.04.2019)

Hacker'lar sosyal medyayı kullanarak vurgun yapıyor (14.03.2019)

Siber ve fiziki dünya iç içe geçti, hacker'lara gün doğdu! (13.03.2019)

Siber korsanların yeni yöntemi çok can yakacak! (12.03.2019)

Almanya'da hacker şoku: Cumhurbaşkanı'nın bile kimlik bilgilerini çaldılar (04.01.2019)

Haber sitesinde hackerları negatif bir biçimde ele alan başlıklarda kullanılan metafor kelime ve söz öbeklerinin şunlar olduğu belirtilebilir:

"saldırl", "korsan", “kurban", "çalma", "çete", "sızma", "hasar", “vurgun",

"can yakma"

Haber sitesinde hackerları tarafsız bir biçimde ele alan haber başlığı ise şudur:

Hacker filminin oyuncuları kimler? İşte Hacker filminin konusu ve oyuncuları (20.06.2019)

Haber sitesinde hackerları pozitif bir biçimde ele alan haber başlıkları ise şunlardır:

Siber tehdide 'beyaz şapkalı' çözüm (21.04.2019)

Amerikalı 'çılgın' girişimcinin 180 yaşına kadar yaşama deneyi (24.06.2019)

Hacker gibi düşünmeyi öğrenerek saldırılardan korunun (11.04.2019) 
Tesla Model 3'ü hackledi, 35 bin dolar ve otomobil kazandı (25.03.2019)

Güvenlik açıklarını ortaya çıkararak bir milyon dolar kazandı (21.03.2019)

Siber alemin muhafizları: Beyaz şapkalı hackerlar (14.03.2019)

Haber sitesinde hackerları pozitif bir biçimde ele alan başlıklarda kullanılan metafor kelime ve söz öbeklerinin şunlar olduğu belirtilebilir:

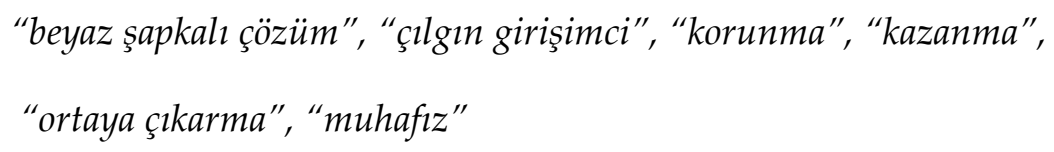

\subsubsection{Haber Girişleri}

Çalışmanın konusu bağlamında hurriyet.com.tr adlı haber sitesinde analiz edilen haber girişlerinin kullanılan başlıklarla paralellik taşıdığı belirtilmelidir.

Hackerları negatif bir biçimde ele alan başlıkların kullanıldığı haberlerin örnek haber girişleri aşağıdadır:

Merkezi $A B D^{\prime}$ de bulunan finansal hizmet şirketi Capital One'ın siber saldırıya uğraması sonucu ABD ve Kanada'dan yaklaşık 106 milyon kullanıcının kişisel verisi çalındı. Olay, $A B D$ tarihinin en büyük veri sızıntılarından biri olarak kabul ediliyor. (30.07.2019)

Güney Amerika ülkesi Brezilya'da Devlet Başkanı Jair Bolsonaro ve ve üst düzey devlet görevlilerinin telefonunu hacklemeye çalıştığı iddia edilen 4 kişi gözaltına alındı. (26.07.2019)

e-posta üzerinden siber saldırı düzenleme sıklığında yillara göre bir azalış olsa da, halen hacker'lar için gözde bir yöntem. Sadece oltalama yöntemiyle yapılan saldırıların bir gün içinde 3.4 milyar sahte e-posta ortaya çıkarması ise durumun ciddiyetini gözler önüne seriyor. (09.07.2019)

Google' in Chrome tarayıcısı kadar olmasa da Mozilla Firefox'un da hatırı sayılır bir kullanıcı kitlesi bulunuyor. Ancak popüler web tarayıcının içinde büyük bir güvenlik açığı ortaya çıktı. Hacker'lar bu açı̆̆ı kullanarak kripto parası olanları hedef alıyor. (20.06.2019)

İstanbul'da, yaşlı ve varlıklı kişilerin bilgilerini kadın hacker C.Y.'den alarak kendilerini polis ve savcı olarak tanıtıp 10 milyon TLIik vurgun yapan elebaşılığını Burak Durdabak'ın yaptığı 8 kişilik çete çökertildi. Çeteye bilgi aktaran kadın hacker her yerde araniyor. (09.05.2019)

İs dünyası ve çalışanlar arasında popüler olan sosyal paylaşım platformu LinkedIn, hackerlerin yeni hedefi haline geldi. Bitdefender Antivirüs, sahte profiller ve iş teklifleriyle 
LinkedIn kullanıcıların tuză̆a düşüren siber korsanlara karşı dikkat edilmesi gerektiğini belirtiyor. (16.04.2019)

Hackerları tarafsız bir biçimde ele alan başlığın kullanıldığı haberin örnek haber girişi aşağıdadır:

Ünlü yönetmen Michael Mann'ın yönettiği 2015 yapımı suç, gerilim, aksiyon filmi 'Hacker' televizyonlarda ilk kez Kanal D ekranlarında izleyiciyle buluşacak. Bu akşam saat 20:00'da yayınlanacak filmde, kimlerin rol aldığı ve genel konusu merak ediliyor. (20.06.2019)

Hackerları pozitif bir biçimde ele alan başlıkların kullanıldığı haberlerin örnek haber girişleri aşağıdadır:

2020 itibariyle 50 milyar cihazın internetle bağlantılı olacağı öngörülüyor. Bu rakam siyah şapkalı hacker ların iştahımı kabartırken kurumlar ise onlara karşı koyabilmek için klasik güvenlik anlayışını bırakıp, 'ofansif güvenlik' anlayışına geçiyor. Bu kapsamda aynı siyah şapkalı hackerlar gibi düşünen, onları kullandıkları platformları bilen beyaz şapkalı hacker Iar istihdam ediliyor. (21.04.2019)

Kendisini "dünyanın ilk profesyonel biyo-hacker'ı" olarak tanımlayan 45 yaşındaki Asprey, altı ayda bir kök hücre elde edebilmek için vücudundan kemik iliği aldırıp sonra bunlart tekrar kendine enjekte ediyor. (24.06.2019)

16 yaşında 'etik dışı' olarak başlayan hacker'ık kariyerini daha sonra etik yöne çeviren Santhosh Tuppad, bir hacker gibi düşünmek isteyenlere ipuçları verdi. (11.04.2019)

Arjantinli beyaz şapkalı hacker Santiago Lopez, internetteki güvenlik açıklarını bularak bir milyon dolar kazanan ilk kişi oldu. (21.03.2019)

Beyaz şapkalı hackerlar, Türkiye'nin enerji tesislerinden bankalarına, dev şirketlerinden kamu kurumlarına kadar stratejik yerlerini "siber korsanlar"dan koruyarak adeta "siber alem muhafizlı̆̆g" yapıyor. (14.03.2019)

\subsubsection{Kelime Seçimleri}

Kelime seçimleri incelendiğinde haber metninin yapısına uygun olduğu görülmektedir. Hackerları suç ile bağlantılı olarak ele alan haber metinlerinde kullanılan kelimeler şunlardır:

"siber saldırı", "siber dolandırıcı", "siber suçlu", "ele geçirme", "çalma", "şebeke",
"gözaltına alma", "hackleme", "hırsızlık", "tuzak", "tehlike", "tehdit", "kurban"

Haber metinlerinde hackerları suç ile mücadele nosyonları doğrultusunda ele alarak pozitif anlamlar yükleyen kelime ve söz öbekleri ise şunlardır: 
"ofansif güvenlik", "beyaz şapkalı hacker", "ödül", "siber güvenlik açıkları", "etik hacker", "gri şapkalı hacker", "biyo-hacker"

\subsubsection{Değerlendirme}

Hurriyet.com.tr adlı İnternet haber sitesi değerlendirildiğinde hackerların genel olarak suç odaklı model doğrultusunda kavramsallaştırıldığı görülmektedir. Altı aylık periyodda konu ile ilgili çıkan elli beş haberden kırk sekizinin hackerları suç odaklı ele aldığı görülmektedir. Sadece altı haberde hackerlar pozitif bir biçimde ele alınmış, onda da yine güvenlik temelli bir bakış açısıyla yaklaşılarak siber güvenliği sağlayabilecek ve etik olmayan yani siyah şapkalı hackerlar ile mücadele edecek kişiler olarak resmedildikleri görülmüştür.

\subsection{Aksam.com.tr}

\subsubsection{Haber Başlıkları}

Çalışmanın konusu bağlamında aksam.com.tr adlı haber sitesinde konu ile ilgili altı aylık zaman dilimi içinde çıan dokuz haber incelenmiş ve incelenen haber başlıklarının beşinde hackerların negatif bir biçimde ele alındığı, üçünde daha tarafsız bir yaklaşımın sergilendiği, birinde ise pozitif bir tutumun benimsendiği görülmüştür.

Haber sitesinde hackerları negatif bir biçimde ele alan başlıklar şunlardır:

The Dark Overlord adlı hacker grubu ABD'yi 11 Eylül ile tehdit etti (02.01.2019)

8 yıllık 'Hayalet' yakayı ele verdi (14.01.2019)

Hackerlarla başı dertte! (22.02.2019)

Banka reklamıyla hacker vurgunu (23.02.2019)

Anonymous: Assange'ın İntikamını alacağız (13.04.2019)

Haber sitesinde hackerları negatif bir biçimde ele alan başlıklarda kullanılan metafor kelime ve deyimlerin şunlar olduğu belirtilebilir:

"tehdit etti", "yakayı ele verdi", "başı dertte", "vurgun", "intikam alma"

Haber sitesinde hackerları tarafsız bir biçimde ele alan bazı haber başlıkları ise şunlardır:

Hacker filmi konusu ne? İşte Chris Hemswortlu Hacker filmi oyuncu kadrosu (20.06.2019)

$5 G$ daha test edilirken bile 'hacker' sensörler devrede' (18.04.2019)

Haber sitesinde hackerları pozitif bir biçimde ele alan haber başlığı ise şudur:

Beyaz yakalı hacker aranıyor (18.01.2019) 
Haber sitesinde hackerları pozitif bir biçimde ele alan başlıkta kullanılan metafor söz öbeğinin ise "Beyaz yakalı hacker" olduğu belirtilmelidir.

\subsubsection{Haber Girişleri}

Çalışmanın konusu bağlamında aksam.com.tr adlı haber sitesinde analiz edilen haber girişlerinin kullanılan başlıklarla paralellik taşıdığı belirtilmelidir.

Hackerları negatif bir biçimde ele alan başlıkların kullanıldı̆̆ı haberlerin örnek haber girişleri aşağıdadır:

Banka müşterilerinin bilgilerini çalıp hesaplarına 200 bin TL geçiren şebeke çökertildi. Hacker çetesinin 500 bin liralık vurgunu da son anda engellendi. (23.02.2019)

Twitter hesabı sürekli olarak hacker saldırısına uğrayan Özge Ulusoy'un başı dertten kurtulmadi. (22.02.2019)

..Ve "Hayalet" kod adlı azılı hacker Ceyhun T. yakalandı. Cep telefonu kullanmayan, 22 ilde yüzlerce kişiyi dolandırarak 8 yıla 115 suç sığdıran "Hayalet", 10 kişilik siber timin çalışmasıyla ele geçirildi. (14.01.2019)

The Dark Overlord adlı hacker grubu, kendilerine bitcoin'le ödeme yapılmaması halinde, sigorta şirketlerinden ve devlet kurumlarından çaldıklarn 11 Eylül'e ilişkin binlerce gizli belgeyi sızdırma tehdidinde bulundu.(02.01.2019)

Hackerları nötr bir biçimde ele alan başlıkların kullanıldığı haberlerin örnek haber girişleri aşağıdadır:

Uluslararası hacker grubu Anonymous, özellikle Sputnik ve Russia Today (RT) çalışmaları ile ilgili belgeler içeren Rusya karşıtı Ingiliz projesi 'Integrity Initiative' belgelerinin bir kısmını daha yayınladı.(26.01.2019)

$5 G$ testlerinden 'hacker' sensörler çıktığımı belirten Ericsson Türkiye Genel Müdürü Işıl Yalçın, "Türkiye'de şebekelerin güvenliğini sağlayacak bir araştırma yapıyoruz" dedi. (18.04.2019)

Hackerları pozitif bir biçimde ele alan başlığın kullanıldı̆̆ı haberin örnek haber girişi aşağıdadır:

Siber güvenlik uzmanı yetiştirmek üzere BTK'nın düzenlediği Siber Yıldız yarışmasının ikincisi 1 Şubat'ta Internet'ten yapulacak (18.01.2019).

\subsubsection{Kelime Seçimleri}

Kelime seçimleri incelendiğinde haber metninin yapısına uygun olduğu görülmektedir.

Hackerları suç ile bağlantılı olarak ele alan haber metinlerinde kullanılan kelime veya söz öbekleri şunlardır: 
"siber saldırı", "siber korsan", "siber dolandırıcıllk", "hacker vurgunu", "hacker saldırısı", "şebeke", "hacker çetesi", "ele geçirme", "tuzağa düşürme", "azılı hacker", "tehdit etme"

Hackerları pozitif olarak ele alan haber metninde kullanılan kelime veya söz öbeği şudur:

"Siber güvenlik uzmanı"

\subsubsection{Değerlendirme}

Aksam.com.tr adlı İnternet haber sitesi değerlendirildiğinde hackerların genel olarak suç odaklı model doğrultusunda kavramsallaştırıldığı görülmektedir. Altı aylık periyodda konu ile ilgili çıkan dokuz haberden beşinin hackerları suç odaklı ele aldığı görülmektedir. Sadece bir haberde hackerlar pozitif bir biçimde ele alınmış, onda da yine güvenlik temelli bir bakış açısıyla yaklaşılarak siber güvenliği sağlayabilecek kişiler olarak resmedildikleri görülmüştür.

\section{Sonuç}

Hackerlık kavramının tarihsel süreç içerisindeki gelişiminin irdelendiği bu çalışmada kavramın 1960'larda kazandığı özgürlükçü yapısının 1980'li yıllardan sonra ortadan kalkmaya başladığını söyleyebilmek mümkün gözükmektedir. Bununla birlikte kavramın geçirdiği dönüşümün izini haber metinleri üzerinde sürdügüumüzde ise 1980'li yıllardan sonra kamusal alanda yaygınlık kazanan suç odaklı yaklaşımlara karşın günümüzde daha pozitif odaklı yaklaşımların da ortaya çıktığı görülmektedir. Yine de bu yaklaşımların suç odaklı hackerlık faaliyetlerine karşı etik hackerlık vurgusu üzerinden gelişen bir nosyon taşıdığı, kavramın özgürlükçü doğasından izler taşımadığı da belirtilmelidir.

Hackerlık kavramı ilk ortaya çıktığında hevesle, tutkuyla bir işi yapan kişiler için kullanılmasına ve paylaşıma yapılan temel vurguya karşılık, 1980'lerden sonra suç ile anılmaya başlamıştır. Hackerlığın özgür yazılım ve açık kaynak kodlu yazılımlardan gelen paylaşım felsefesi ile tutkuyla yeni teknolojik üretimler gerçekleştirme biçiminde taşıdığ pozitif kavramsallık anlamını gittikçe yitirerek toplumda suç odaklı kırıcılık faaliyetleri ile eşdeğer tutulmaya başlanmış ve hackerlık yaygın bir biçimde bilgisayar hırsızlı̆̆ı ve korsanlığı olarak nitelenmiştir. Hackerların özellikle de medyanın da kendilerini yansıttığ1 biçimde suç ile bağlantılı olmadıklarını vurgulamaya çalıştığı ve suç ile bağlantılı kişileri cracker olarak nitelediği de belirtilmelidir.

Yapılan bu çalışmada medyadaki haberlerde Fowler'ın da üzerinde durduğu gibi "biz" ve "öteki" karşıtlı̆̆1 yeniden üretilerek hackerların "öteki" olarak damgalandığ 1 ve bu anlamda da genel olarak suç ve kırıcılık faaliyetleri ile bağlantılı kişiler olarak resmedildiği görülür. Bununla birlikte çok az olmakla birlikte etik ya da beyaz şapkalı hacker denilen ifadelendirmelerin de kullanıldığı söylenmelidir. Özellikle de Hürriyet gazetesinin web sayfasında konuya ilişkin çok sayıda habere rastlanmıştır. Altı aylık zaman dilimi içinde hacker temalı haberlerin toplam sayısının elli beş olduğu görülmektedir. Bu elli beş haberin 
kırk sekizinde hackerların suç odaklı hareket ettiği ve kırıcılık yaptıkları ifade edilirken, altısında ise hackerlar beyaz şapkalı olarak tarif edilmiş ve kırıcılık yapanlarla mücadele eden bir biçimde sunulmuştur. Yine aksam.com.tr ve ensonhaber.com adlı İnternet haber sitelerinde de hackerlık kavramının ele alış biçiminin çoğunlukla negatif bir söylemsel kapanma taşıdığ1 görülmektedir. Kavram bu sitelerde pozitif anlamda çok az bir sayıda kullanılmıştır. Akşam gazetesinin İnternet haber sitesinde altı aylık zaman dilimi içinde çıkan dokuz haberden beşi hackerlığı suç odaklı tanımlarken, sadece bir haber pozitif yönde bir yaklaşım sergilemiştir. Ensonhaber.com adlı haber sitesinde ise konu ile ilgili altı aylık bir zaman dilimi içinde çıkan dört haberin üçünde hackerların negatif bir biçimde ele alındığı, pozitif yönden ise hiç ele alınmadığı görülür. Bu anlamda haber metinleri eleştirel söylem analizine tabi tutulduğunda medyanın ürettiği hackerlık yaklaşımının özgürlükçü modelden ziyade suç odaklı modele yakın olduğu belirtilmelidir. Yine de son yıllarda kavram üzerinde süregiden mücadele sonucunda etik hackerlık denilen bir yaklaşımın da haber metinlerinde kendisine yer bulduğu görülmektedir. Özellikle de Hürriyet gazetesinin İnternet haber sitesinde bu konuda haberler kendisine yer bulabilmiştir. Bununla birikte beyaz şapkalı ya da etik hackerlık diye adlandırılan tanımlamaların hackerlığın tarihsel gelişiminde de görüldüğü gibi özgürlükçü bir modelin söylemsel ardalanı olduğunu söylemek mümkün gözükmemektedir. Etik hackerlık kavramının suç odaklı hackerlık faaliyetini engelleme temelli geliştiği görülürken bu anlamda da ilk dönem hackerlığın paylaşım değerleri nosyonlu özgürlükçü söylemi yerine güvenlik ve koruma temelli söylemin medyada yeniden üretildiği belirtilmelidir.

\section{Kaynakça}

Akdeniz, G. (2013). Hacker Etiği. Hack Kültürü ve Hacktivizm: Yeni Bir Siyaset Biçimi içinde. Keleş, A. R. ve Sal, Y. (Der.). İstanbul: Alternatif Bilişim Yayınları, ss. 9-15.

Alexa. (2019). Erişim Tarihi: 27.07.2019. https://www.alexa.com/topsites/countries/TR

Anar, A. (2006). Bir Emekçi Olarak 'Hacker' Kimdir? Erişim Tarihi: 11.06.2019. http://www.bianet.org/2006/06/16/80764.htm

Atabek, Ü. (2005). İletişim Teknolojileri ve Yerel Medya İçin Olanaklar. Yeni İletişim Teknolojileri ve Medya içinde. Alankuş, S. (Der.). İstanbul: IPS İletişim Vakfı Yayınları, ss. 61-91.

Baker, P., Gabrielatos, C., \& McEnery, T. (2013). Discourse Analysis and Media Attitudes: The Representation of Islam in the British Press. Cambridge: Cambridge University Press.

Boschele, F. A. ve Öztürk, Ö. Ç. (2017). Dijital İletişim Teknoojileri ve Toplumsal Hareketler Bağlamında Hacktivizm. Üsküdar Üniversitesi Sosyal Bilimler Dergisi, 3 (5), 429-452.

Bronk, C., \& Ringas, E.T. (2013). Hack or Attack? Shamoon and the Evolution of Cyber Conflict, Rice University Baker Institute Working Paper.

Brown, G., \& Yule, G. (1983). In Discourse Analysis (Cambridge Textbooks in Linguistics). 
Cambridge: Cambridge University Press.

Castells, M. (2005). Enformasyonculuk ve Network Toplumu. Hacker Etiğgi içinde. Himanen,

P. (Der.), Kaptan, Ş. (Çev.). İstanbul: Ayrıntı Yayınları, ss.145-160.

Castells, M. (2010). The Rise of the Network Society, The Information Age: Economy, Society, and Culture. Malden: Wiley- Blackwell Press.

Eriş, U. (2011). Türkiye'de Hacker (Kırıcı) Kültürü. Gümüşhane Üniversitesi İletişim Fakültesi Elektronik Dergisi, 1 (2), 22- 44.

Fairclough, N. L. \& Wodak, R. (1997). Critical discourse analysis. In T. A. van Dijk (ed.), Discourse Studies. A Multidisciplinary Introduction. London: Sage, s. 258-84.

Fowler, R. (1991). Langue In The News: Discourse and Ideology in the Press. London: Routledge.

Gabriel W. (2006). Terror on The Internet: The New Arena The New Challenges, Washington D.C., United States Institue of Peace.

Gunkel, D. J. (2005). Editorial: Introduction to Hacking and Hacktivism. New Media \& Society, 7(5), 595597.

Halbert, D. (1997). Discourses of Danger and the Computer Hacker. The Information Society,

$13,361-374$

Hekim, H. ve Başıbüyük, O. (2013). Siber Suçlar ve Türkiye'nin Siber Güvenlik Politikaları. Uluslararası Güvenlik ve Terörizm Dergisi, 4 (2), 135-158.

Himanen, P. (2005). Hacker Etiği. Şebnem Kaptan (Çev.). İstanbul: Ayrıntı Yayınları.

İnal, A. (1996). Haberi Okumak. İstanbul: Temuçin Yayınevi.

Levy, S. (1984). Hackers, Heroes of the Computer Revolution. Erişim Tarihi: 10.06.2019. https://kupdf.net/download/steven-levy- hackers_5b01bdeee2b6f5c01b702060_pdf

$\begin{array}{llllll}\text { NATO. (2018). Cyber } & \text { Defence. } & \text { Erişim } & \text { Tarihi: } & \text { 13.04.2019. }\end{array}$ https://www.nato.int/cps/en/natohq/topics_78170.htm?

Öğün, M. N. ve Kaya, A. (2013). Siber Güvenliğin Milli Güvenlik Açısından Önemi ve Alınabilecek Tedbirler. Güvenlik Sratejileri Dergisi, 9 (18), 145-181.

Özer, Ö. (2009). Eleştirel Haber Çözümlemeleri. Eskişehir: Anadolu Üniversitesi İletişim Bilimleri Fakültesi Yayınları.

Paul A. T. (1999). Hackers Crime In The Digital Sublime. New York: Routledge.

Raymond, E. S. (2006). Nasıl Hacker Olunur? Erişim Tarihi: 11.01.2019. http://docs.comu.edu.tr/howto/hacker-howto.html

Raymond, E. S. (2008). Katedral ve Pazar. Ankara: Elektrik Mühendisleri Odası Yayınları. 
Sabancı, A. (2013). Hackerlara bir karşı kültür olarak bakmak. Hack Kültürü ve Hacktivizm:

Yeni Bir Siyaset Biçimi içinde. Keleş, A. R. ve Sal, Y. (Der.). İstanbul: Alternatif Bilişim Yayınları, ss. 1626.

Saka, E. (2013). Hackerlık Üzerine Birkaç Gözlem. Hack Kültürü ve Hacktivizm: Yeni Bir Siyaset Biçimi içinde. Keleş, A. R. ve Sal, Y. (Der.). İstanbul: Alternatif Bilişim Yayınları, ss. 34-40.

Şenel, A. (2011). Siyasal Düşünceler Tarihi. Ankara: Bilim ve Sanat Yayınları.

Taş, O. (2012). Gazetecilik Etiğinin Mesleki Sınırları. İstanbul: İletişim Yayınları.

TDK. (2019). Hacker. Erişim Tarihi: 20.06.2019. http://sozluk.gov.tr/.

Terzi, M. (2018). Bilgi ve İletişim Teknolojilerine Dayalı Oluşumlar ile Bu Oluşumların Uluslararası İlişkilere Güvenlik Bağlamındaki Etkisi: Siber Terörizm. Kara Harp Okulu Bilim Dergisi, 28 (1), 73-108.

The New Hacker's Dictionary. (2018). Erişim Tarihi: 16.03.2018. http://www.dominiopublico.gov.br/download/texto/gu003008.pdf

Timisi, N. (2003). Yeni İletişim Teknolojileri ve Demokrasi. Ankara: Dost Kitabevi.

Torvalds, L. (2005). Hacker'lık Dürtüsü Nereden Gelir? Öteki Adıyla Linus Yasası. Hacker Etiğgi içinde. Himanen, P. (Der.). Kaptan, Ş. (Çev.). İstanbul: Ayrıntı Yayınları, ss.14-18.

TÜBA. (2019). Hacker. Erişim Tarihi: 20.06.2019. http://www.tubaterim.gov.tr/

Uçkan, Ö. (2013a). Hacker'lar: Viral Kültürün Semantik Gerillaları mı, Enformasyon Toplumunun Veri Hırsızları mı? Hack Kültürü ve Hacktivizm: Yeni Bir Siyaset Biçimi içinde. Keleş, A. R. ve Sal, Y. (Der.). İstanbul: Alternatif Bilişim Yayınları, ss. 41-47.

Uçkan, Ö. (2013b). Dijital Aktivizmin Sınır Boyunda Hacktivizm: Anonymous ve RedHack örnekleri. Hack Kültürü ve Hacktivizm: Yeni Bir Siyaset Biçimi içinde. Keleş, A. R. ve Sal, Y. (Der.). İstanbul: Alternatif Bilişim Yayınları, ss. 53- 79.

Van Dijk, T. A. (2001). Critical Discourse Analysis. In The Handbook of Discourse Analysis. Schiffrin, D., Tannen, D., \& Hamilton, E. H. (Ed.). Oxford: Blakwell Publishing, pp. 352-371.

Walleij, L. (2003) Copyright Does Not Exist: A Book About Information and Power, For Everyone and For No One. Erişim Tarihi: 09.12.2019. http://www.devili.iki.fi/pub/misc/books/cdne.pdf

WEF (World Economic Forum). (2019). The Global Risks Report 2019. Erişim Tarihi: 08.11.2019. http://www3.weforum.org/docs/WEF_Global_Risks_Report_2019.pdf

Yor, M. and Steinmetz, K. F. (2019). Cybercrime and Society. London: Sage Publications. 